Bartın University Journal of Faculty of Economics and Administrative Sciences, 2021, Volume 12, Issue 24

\title{
Bireysel Müşterilerin Kredi Kullanımlarında Katılım Bankalarını Tercih Etme Sebepleri Üzerine Bir Araştırma: Bolu Örneği ${ }^{1}$
}

\author{
Hacer KARAKAŞ İŞCAN \\ Doktora Öğrencisi, Bolu Abant İzzet Baysal Üniversitesi SBE, Bankacılık ve Finans ABD \\ hacerkarakas14@gmail.com, OrcID: 0000-0001-5994-1348
}

Prof. Dr. Ferudun KAYA

Bolu Abant İzzet Baysal Üniversitesi, Bankacılık ve Finans ABD kayaferudun@gmail.com, OrcID: 0000-0002-8930-9711

\section{Öz}

Çalışmada, bireysel müşterilerin kredi kullanımlarında katılım bankalarını tercih etme nedenlerinin tespit edilmesi amaçlanmıştır. Ayrıca kredi kullanımında katılım bankası tercihini etkileyen faktörlerin demografik değişkenlere göre farklılık gösterip göstermediği tespit edilmeye çalışılmıştır. Araştırmada Bolu ilinde yaşayan bireysel müşterilere anket uygulanmış, verilerin analiz edilmesinde SPSS programından yararlanılmıştır. İstatistiksel veriler elde edilirken örneklemin bilgilerini sayısal olarak özetleyebilmek için betimleyici analiz, ölçeğin güvenilirliği ve geçerliliğini tespit etmek için faktör analizi, değişkenlerin orta değerden farklı olup olmadığını ölçmek için t testi uygulanmıştır. Kredi kullanımında katılım bankası tercihini etkileyen faktörlerin demografik değişkenlere göre farklılık gösterip göstermediğini tespit etmek için varyans analizi yapılmıştır. Çalışmadan elde edilen bulgulara göre bireysel müşterilerin kredi kullanımlarında katılım bankalarını tercih etmesini etkileyen en önemli değişken; faizsiz bankacılık uygulamasıdır. Araştırmada, kredi kullanımlarında bireysel müşterilerin, katılım bankalarını tercih etmesinde demografik özelliklerinin etkilediği bulgusuna ulaşılmıştır.

Anahtar Kelimeler: Katılım Bankacılığı, Bireysel Müşteri, Finans

JEL Sınıflandırmaları: G21, Z00

\footnotetext{
${ }^{1}$ Bu çalışmada "Bireysel Müşterilerin Kredi Kullanımlarında Katılım Bankalarını Tercih Etme Sebepleri" (Bolu,Abant İzzet Baysal Üniversitesi, Sosyal Bilimler Enstitüsü) adlı yüksek lisans tezinden faydalanılmıștır. Çalışma, 3-6 Ekim 2nd International Conference on Data Science and Applications (ICONDATA'19) ve 7-8 Aralık Uluslararası İslam Ekonomisi, Finans ve Etik (ISEFE) Kongreleri’nde sözlü bildiri olarak sunulmuş ve sempozyum kitapçığında tam metin olarak basılmıştır.

APA: Karakaş İşcan, H. ve Kaya, F. (2021). Bireysel Müşterilerin Kredi Kullanımlarında Katılım Bankalarını Tercih Etme Sebepleri Üzerine Bir Araştırma: Bolu Örneği. Bartın Üniversitesi İktisadi ve İdari Bilimler Fakültesi Dergisi, 12 (24), 467-492.

APA: Karakaş İşcan, H. ve Kaya, F. (2021). The Reasons for Retail Customers' Preference for Participation Banks in their Use of Loans. Bartın University Journal of Faculty of Economics and Administrative Sciences, 12 (24), 467-492.
} 


\title{
The Reasons for Retail Customers' Preference for Participation Banks in their Use of Loans
}

\begin{abstract}
The aim of the study reasons for which retail customers choose to receive loans from participation banks, and to assess whether factors influencing customers' preference for participation banks differ according to demographic variables. To this end, a survey was conducted on retail customers living in Bolu and survey data analyzed via SPSS package software. Descriptive analysis were used to summarize the data from the sample numerically, factor analysis used to determine the reliability and validity of the scale, and t-test used to ascertain if variables differed from the median value. The assessment of whether factors that influenced the preference for participation banks in receiving loans differed according to demographics was done through variance analysis. The findings suggested that interest-free banking practices constituted the most significant variable that led retail customers to choose to receive loans from participation banks. Demographic variables were also found to influence retail customers' preference for participation banks in taking out loans.
\end{abstract}

Keywords: Participation Banking, Retail Customers, Finance

JEL Classification: G21, Z00

\section{Giriş}

Faizsiz bankacılık Türkiye ve Dünyada giderek yaygınlaşmış ve ekonomide önemli bir yer edinmiştir. Bunun birçok nedeni vardır. Müşterilerin tasarruflarını faizsiz olarak değerlendirebilmesi için Katılım Bankaları tercih edilmektedir. Konvansiyonel bankalarda tasarruflarını değerlendiren bireysel ve ticari müşteriler de Katılım Bankalarını tercih edebilmektedir. Günümüzde Katılım Bankacılığının verdiği hizmetlerden yararlanan çok sayıda müşteri bulunmaktadır. Katılım bankaları kendileri için uygun ve doğru müşterileri işletmesine kazandırmak ve müşterilerini kaybetmemek için uğraşmaktadır. Bunun içinde müşterilerin ihtiyaçlarını ve onları nelerin daha çok etkilediğini izleyip öğrenen sistemler oluşturmaları gerekmektedir.

Günümüzde bankalar arasında rekabet çok artmıştır. Katılım bankaları da bankacılık sektöründe rekabet halindedir. Bankalar müşterileri bankasına kazandırmak için farklılıklar yaratarak onları müşterileri yapmak istemektedirler. Farklılık yaratmaları yeterli olmayarak bununla birlikte sadık müşteri yapabilme yöntemleri de geliştirmektedirler. Müşterilerin sadakatini güçlü kılmanın yollarından biri de, rakip olan bankalara gitmesini engelleyici tedbirler almaktır. Burada sadık olan müşterilere avantajlı ürünler sunulmakta ve sadık müşterilerde rakip bankalardan gelen bazı 
teklifleri geri çevirmektedir. Bu noktada bireysel müşteriler bankalar açısından son derece önemlidir. Daha önce bireysel müşterilere yönelik çalışmalar yapılmıştır fakat bireysel müşterilerin kredi kullanımındaki katılım bankası tercihine yönelik yapılmış çalışma bulunmamaktadır. Yapılan bu çalışmayla literatürdeki bu boşluğun doldurulması amaçlanmaktadır. Yapılan araştırmada, bireysel müşterilerin kredi kullanımlarında katılım bankalarını tercih etmelerini etkileyen sebeplerin neler olduğu ile ilgili sorulara cevap aranmaya çalışılmıştır. Araştırmanın amacı doğrultusunda ayrıca katılım bankasını tercih eden müşterilerin demografik değişkenleriyle katılım bankası tercihine etki eden faktörler arasında anlamlı bir ilişki olup olmadığı da test edilmiştir.

\section{Literatür Taraması}

Karakaya vd (2004), Katılım bankası müşterisi kişilerin banka tercihine etki eden faktörleri araştırmak ve müşterilerin memnuniyetini ölçmek için araştırma yapılmıştır. İstanbul'da yapılan çalışmada müşterilerin banka tercihini etkileyen faktörler olarak; İslami sebepler, aile ve tanıdık kişilerin etkisi, getiri oranları ve banka imajı şeklinde görülmüş̧tür.

Okumuş (2005), İstanbul'da yaptığı çalışmada, katılım bankalarındaki tercih kriterlerini araştırabilmek için bireysel müşterilere anket uygulanmıştır. Yapılan ankette dini hassasiyet birinci faktör olarak yer almıştır. Faktörün en önemli değişkeni faiz değişkeni olduğu görülmüştür.

Eskici (2007), ülkemizde faaliyet gösteren dört farklı Katılım Bankası müşterilerine anket uygulanmıştır. Müşterilerin öncelikli olarak faiz hassasiyetlerinden dolayı bu bankalarla çalıştıkları ortaya çıkmıştır. Diğer nedenler olarak da; çalışma kalitesi, güvenilirlik, ürün çeşitliliği, çalışma hızı, rekabet edebilirliği ve uygulanan masraf ya da komisyon oranları görülmektedir.

Dusuki vd (2007), İslami bankacılığı tercih etmede etkili olan nedenleri belirlemek için Malezya'nın dört farklı bölgesinde anket uygulanmıştır. Banka tercihlerinde İslam hukukuna uygun hareket etmeleri ve kaliteli hizmet sunmaları en önemli nedenler olarak görülmüştür. Tercih nedenleri arasında sosyal sorumluluk uygulamaları, şubenin ev ya da iş yerine yakın olması ve sunulan hizmetlerin fiyatı diğer önemli nedenleri oluşturmuştur.

Amin (2008), İslami bankacılığı tercih etme sebepleri üzerine bir araştırma yapılmıştır. Malezya'da yapılan araştırmada faizin uygulanmaması, kredi oranlarının düşük olması ve şeffaf olmaları müşterilerin tercih etmelerini etkileyen faktörler olarak görülmüştür.

Al-Ajmi vd (2009), Bahreyn'de İslami bankalarla mevduat bankalarının tercih edilmesinde etkili olan faktörleri araştırmak için bir çalışma yapılmıştır. Çalışmada 

Participation Banks in their Use of Loans

anket tekniğinden yararlanılmıştır. Araştırma sonucu olarak; İnanç, hizmet kalitesi, sosyal sorumluluk, etkinlik, lokasyon ve personel yaklaşımı açısından yakınlık bankaları tercih etmede etkili olan faktörler olarak görülmüştür.

Bhatti vd (2010), İslami bankaların sunduğu hizmetlerden faydalanan bireylere, bu bankaları tercih etme nedenleri üzerine Pakistan'da bir araştırma yapılmıştır. Yapılan çalışmada karlılık ve dini nedenler önemli etkiler olarak görülmüştür.

Marimuthu vd (2010) tarafindan Malezya'da yapılan araştırmada faizsiz bankacılığı tercih etmeye yönelik fayda- maliyet ilişkisi birinci tercih edilme sebebi olarak görülmüştür. Sırayla; hizmetin sunumu, kullanıma uygunluğu, dini sebepler, tanıdıkların etkisi, aktif büyüklüğü ve bankada çalışanların etkisi sebebiyle faizsiz bankaları tercih ettikleri sonucuna varılmıştır.

Khattak ve Ur-Rehman (2010) tarafından yapılan çalışmada faizsiz bankacılık müşterilerinin demografik özelliklerine göre memnuniyeti ve farkındalık düzeyi analiz edilmiştir. Yapılan çalışma Pakistan'da, müşteri portföyünün eğitim düzeyinin yüksek olduğu ve 21-40 yaş aralığı içerisinde orta gelirden oluştukları tespit edilmiştir. Müşterilerin büyük bir bölümü İslami nedenlerden ötürü faizsiz bankaları tercih etmiştir. Bu faktör dışındaki bankacılık işlemlerinde etkinlik ve hız, müşteriye güven vermeleri ve çalışma saatlerindeki esnekliğin önemli olduğu görülmüştür. Katılım bankası müşterilerinin faizsiz bankacılık ürünlerini kullandıkları ve bu ürünlerden memnun oldukları ancak diğer katılım bankacılığg ürünlerinden haberdar olmadıkları sonucuna ulaşmışlardır.

Lee vd (2011), İslamabad (Pakistan) ve Peshawar şehirlerinde yapılan çalışmada anket tekniğinden yararlanılmıştır. Müşterilerin İslam hukukuna göre hareket etmelerinden dolayı İslami bankaları tercih ettikleri sonucuna ulaşılmıştır.

Abduh ve Mohd (2012), Malezya'da yapılan çalışmada faizsiz bankaların tercih edilme nedenlerini belirlemeye yönelik bir araştırma yapılmıştır. Araştırma anket çalışmasına dayalı yapılmıştır. Tercih edilme nedenlerinde dini duyarlılık ve faiz hassasiyeti önemli yer almıştır.

Özsoy vd. (2013) Türkiye'de katılım bankalarını tercih etme sebepleri üzerine bir çalışma yapılmıştır. Bolu ilinde yapılan çalışmada üç farklı katılım bankası müşterileri ele alınmıştır. 217 kişiye uygulanan anketle veriler toplanmıştır ve açıklayıcı faktör analizi uygulanmıştır. Elde edilen verilere göre katılan kişilerin katılım bankası tercihlerini etkileyen en önemli faktör Hizmet ve Ürün kalitesi olmuştur. Sırasıyla, İmaj ve güven, personelin kalitesi ve dini/çevresel motivasyon faktörleri etkilemiştir.

Ramadan (2013), Ürdün'deki müşterilerin faizsiz banka tercih kriterleri üzerine bir araştırma yapılmıştır. Yapılan önem derecesi sıralamasında; güler yüzlülük, 
ürünlerin fiyatı, İslami imaj ilk üç sırada yer alanlardır. Dini sebeplerden dolayı İslami bankacılık tercih edilmemiştir sonucuna ulaşılmıştır. Yapılan sıralamada faizsiz bankanın konumu, eve veya iş yerine yakınlığı son üç sırada yer alanlardır. Müşterilerin potansiyel ve mevcut istek ve ihtiyaçlarını İslami bankaların tespit ederek bankacılık ürünlerini geliştirmesi gerektiği sonucu elde edilmiştir.

Toroman vd. (2015) Mevcut ve potansiyel banka müşterilerinde İslami bankacılık faaliyetlerine yönelik müşteri algısı üzerine çalışma yapılmıştır. Yapılan anket sonuçlarında İslami banka ile çalışan, çalışmayan ya da kararsız kalan katılımcıların tüm sorulara verdikleri cevaplar arasında anlamlı farklılıklar görülmüştür. Müşterilerin yeterince bilmediği ve İslami finans algısının düşük olduğu sonucuna varılmıştır.

Anaç ve Kaya (2017), Bireysel müşterilerin katılım bankacılığını tercih etmesini etkileyen faktörler üzerine araştırma yapılmıştır. 423 kişiye anket uygulanarak veriler elde edilmiştir. Verilere açıklayıcı faktör analizi uygulanmıştır. Elde edilen sonuca göre bireysel müşterilerin katılım bankasını tercih etmede önemli olan faktörler olarak; Katılım bankası ve faizsiz kurum olarak imajı ve popülaritesi, dini hassasiyetlerin yönlendirmesi ve banka çalışanlarının müşterilere olan yaklaşımı şeklinde olmuştur.

Durak vd. (2017), Banka seçiminde müşteri tercihlerinin katılım bankalarına yönelik bir araştırması yapılmıştır. Bolu, Düzce ve Zonguldak illerinde yapılan araştırmada anket tekniğinden yararlanılmıştır. İki faktörün tercih etmede önemli olduğu sonucuna ulaşılarak SPSS programında anova testi ile test edilmiştir. En etkili neden olarak da şube personeli ile yakın ilişkiler olduğu sonucuna ulaşılmıştır.

Öndeş vd. (2018), Katılım bankalarının kredi kullananlar açısından tercih edilmeme sebeplerini araştırmışlardır. $\mathrm{Bu}$ araştırma Atatürk üniversitesindeki akademisyenler üzerinde uygulanmıştır. Anket tekniğinden yararlanılarak SPSS programı kullanılmıştır. Verilere Frekans ve Ki-Kare analizleri yapılmıştır. Ürün çeşitliliğinin yetersizliği, doğrudan finansman ihtiyacının karşılanamaması, finansman maliyetlerinin yüksekliği, şube ve ATM sayısının yetersiz oluşu katılım bankalarını tercih etmeme sebepleri olarak görülmüştür.

\section{Metodoloji}

\subsection{Araştırmanın Amacı ve Önemi}

Çalışmada, bireysel müşterilerin demografik özelliklerinin katılım bankası tercihlerine etkisi olup olmadığının araştırılması amaçlanmıştır. Ayrıca bireysel müşterilerin kredi kullanımlarında katılım bankalarını tercih etme sebeplerine etki eden faktörleri tespit etmekte çalışmanın bir diğer amacıdır. Bankalara sınırlı kaynaklarını 
etkin ve verimli kullanabilmesi ve bireysel müşterilerinin istek ve ihtiyaçlarını karşılamada müşteri tatmini sağlayabilmeleri için öneriler geliştirilmesi hedeflenmiştir.

\subsection{Araştırmanın Yöntemi}

Çalışmada, araştırma yöntemi olarak kesitsel yöntemlerden faydalanılarak veriler birincil kaynaklardan elde edilmiştir. Katılım bankaları ile çalışan bireysel müşterilerden ana kütleyi temsil edecek örnek kütleye anket yöntemi uygulaması benimsenmiştir.

Anket formu içerisinde bulunan çoktan seçmeli sorular, katılım bankaları ile çalışan bireysel müşterilere kolayca cevaplayabilecek biçimde hazırlanmıştır. Uygulanan anket iki bölümden oluşmaktadır. Birinci bölümde, katılım bankası müşterilerinin demografik özellikleri ve katılım bankası ile ilgili sorulardan oluşan toplam on beş soru bulunmaktadır. İkinci bölümde ise bireysel müşterilerin kredi kullanımlarında katılım bankalarını tercih etme sebeplerini belirlemeye yönelik yirmi dokuz soru bulunmaktadır. İkinci bölümde, katılım bankalarının sahip olduğu özellikler ve sunduğu hizmetlere dayalı yargılarda beşli likert tipi ölçeğe göre hazırlanmıştır.

Uygulama kısmında kullanılacak ölçeklerin cevaplayanlar tarafindan anlaşılır olduğunun tespiti için ön çalışma yapılmıştır. Ön çalışmada, katılım bankalarını tercih nedenleriyle ilgili sorular ve bu soruların şıklarında yanlışlığa ya da eksikliğe sebep olmaması için tesadüfi örnekleme ile seçilen 18 yaşın üzerinde ve katılım bankası müşterisi olan 45 bireysel müşteriye anket yapılmış ve anlamada zorlanılan sorular düzeltilmiştir. Düzeltme aşaması sonrasında anketin geçerli olup olmadığını değerlendirmek için üniversitede görev alan ve konuyla ilgili bilgi sahibi olan akademisyenlerin görüşleriyle düzeltmeler yapılmış ve bu sonuçlar neticesinde anket formundaki soruların anlaşılır olup olmadığı test edilerek anket son halini almıştır. Anketler, Bolu ilinde 45 kişiye yüz yüze görüşme yöntemi ile kesin anket formunu hazırlamadan önce soruların güvenilirliğini ölçmek için araştırmanın örneğini temsil etmesi için ön test yapılmıştır. Elde edilen 45 anket formunun ön test analizinin yapılmasına karar verilip SPSS paket programına verilerin kodlaması yapılmıştır. Ön testin istatiksel analiz sonucu, bulgularda varyans analizi yapılarak test edilecek faktör yapıları ortaya konulmuştur. Katılım bankasını tercih etmesini tespit etmeye yarayan 29 yarg1 ve 15 sorudan oluşan anket formu iki sayfadan oluşmakta ve 10-15 dakikada yanitlanabilmektedir.

\subsection{Araştırmanın Evreni ve Örneklemi}

Türkiye genelinde katılım bankalarıyla çalışan aktif bireysel müşteri sayısı TKBB'ye göre 4.418.039 kişidir (www.tkbb.org.tr, 17 Mart 2019'da erişildi). Örneklem yöntemi olarak Kolayda örnekleme yöntemiyle veriler elde edilmiştir. Katılım bankaları ve diğer bankaların müşterilerle ilgili bilgi vermeleri hukuka aykırı olması sebebiyle, araştırmada geçen veriler, katılım bankası ile çalışan müşteriler ile yüz yüze görüşülerek 
hazırlanan anket formunun işaretlenmesi ile elde edilmiştir. Araştırmaya katılan kişilere katılım bankası müşterisi olup olmadığı eğer katılım bankası müşterisi ise bireysel kredi ile ilgili durumu sorularak anketleri cevaplandırmaları istenmiştir. Araştırmada ankete katılan kişiler bireysel kredi kullanan kişilerdir. Araştırmada veri elde etme aracı ise kapalı uçlu sorulardan oluşan anket formunun işaretlenmesi ile elde edilmiştir. Araştırmanın veri elde etme aracı olarak kapalı uçlu sorulardan oluşan anket formundan faydalanılmıştır. Bolu ilinde yaşamakta olan 18 yaş ve üzeri katılım bankası müşterisi olanlar araştırmanın evrenini oluşturmaktadır. 2018 yılı genel nüfus sonuçlarına göre Bolu'da 311.810 kişi ikamet etmektedir (https://www.nufusu.com.tr, Erişim Tarihi; 17.03.2019). Örneklemin büyüklüğünü etkilemede en önemli faktör anlamlılık düzeyidir. Sosyal bilimlere yönelik yapılan araştırmalarda genellikle 0,05 anlamlılık düzeyi yeterli bulunmaktadır. Çalışmamızda 450 kişiye anket uygulanmıştır. Ön çalışmada bu sayının yaklaşık olarak 1/100.000 kişiye denk gelen 45 kişiye anket yapılmış, daha sonra ise yaklaşık 1/10.000'e göre 450 anket hazırlanıp uygulamaya konulmuştur. Araştırma genelinde, örnek kitleden anket yoluyla sağlanan verilerin 400 tanesi analize elverişli olduğu tespit edilmiştir.

Evrende örneklem seçimi yoluna gidilmiş, Bolu ilindeki örneklem seçiminde araştırmanın ana konusuyla doğru orantılı olarak katılım bankalarının yoğun kullanıldığı yerlerden faydalanılmıştır.

\subsection{Araştırmanın Değişkenleri ve Hipotezi}

Araştırmanın hedefleri doğrultusunda bireysel müşterilerin kredi kullanımlarında katılım bankalarını tercih etme sebeplerine etki eden değişkenler bağımlı ve bağımsız değişken olarak iki grup halinde incelenmiştir. Birinci grupta demografik değişkenler (cinsiyet, medeni durum, yaş gibi,), ikinci grupta da davranışsal değişkenler yer almıştır. Araştırmada bireysel müşterilerin kredi kullanımlarında katılım bankaları ile çalışmasına yönelik tutumlarını ölçmek amacıyla 29 yargı (bağımlı değişken) belirlenmiştir.

Katılım bankaları, bireysel müşterilere sunduğu hizmetlerin çeşitliliği ve etkinliğini arttırarak, tercih edilebilirliğini arttıracağını ortaya koymak için araştırma modeli kapsamında ileri sürülen ve bireysel müşterilerin demografik özellikleriyle tercih ettikleri katılım bankalarının yapısı ve sundukları hizmetler arasında anlamlı ilişki olup olmadığını test etmek amacıyla oluşturulan hipotezler aşağıda verilmiştir.

Ho: Bireysel müşterilerin demografik özellikleri (bağımsız değişkenler) ile kredi kullanımlarında katılım bankalarını tercih etme sebeplerinde etkili olan faktörler arasında (bağımlı değişkenler) anlamlı bir ilişki yoktur.

$\mathrm{H}_{1}$ : Bireysel müşterilerin demografik özellikleri (bağımsız değişkenler) ile kredi kullanımlarında katılım bankalarını tercih etme sebeplerinde etkili olan faktörler arasında (bağımlı değişkenler) anlamlı bir ilişki vardır. 


\section{Verilerin Analizi ve Bulgular}

\subsection{Betimsel Analiz}

Araştırmada yapılan ankette bireysel müşterilerin demografik özellikleri Tablo 1'de gösterilmiştir.

Tablo 1: Bireysel Müşterilerin Demografik Özellikleri

\begin{tabular}{|c|c|c|}
\hline Cinsiyet & Kişi Sayısı & $\operatorname{Oran}(\%)$ \\
\hline Bay & 190 & 47,5 \\
\hline Bayan & 210 & 52,5 \\
\hline Yaş & Kişi Sayısı & $\operatorname{Oran}(\%)$ \\
\hline $18-25$ & 86 & 21,5 \\
\hline $26-35$ & 132 & 33,0 \\
\hline $36-45$ & 111 & 27,8 \\
\hline $46-55$ & 51 & 12,8 \\
\hline 56 ve üzeri & 20 & 5,0 \\
\hline Medeni Durum & Kişi Sayısı & $\operatorname{Oran}(\%)$ \\
\hline Evli & 236 & 59,0 \\
\hline Bekar & 164 & 41,0 \\
\hline Öğrenim Durumu & Kişi Sayısı & Oran $(\%)$ \\
\hline Ortaokul & 47 & 11,8 \\
\hline Lise & 105 & 26,3 \\
\hline Ön Lisans & 61 & 15,3 \\
\hline Lisans & 146 & 36,5 \\
\hline Lisansüstü & 41 & 10,3 \\
\hline Meslek & Kişi Sayısı & $\operatorname{Oran}(\%)$ \\
\hline Öğrenci/Çalışmıyor & 125 & 31,3 \\
\hline Kamu Sektörü & 82 & 20,5 \\
\hline Özel Sektör & 131 & 32,8 \\
\hline Emekli & 23 & 5,8 \\
\hline Esnaf/Serbest Meslek & 39 & 9,8 \\
\hline Aylık Gelir & Kişi Sayısı & $\operatorname{Oran}(\%)$ \\
\hline $0-1500 \mathrm{TL}$ & 121 & 30,3 \\
\hline $1501-2500 \mathrm{TL}$ & 94 & 23,5 \\
\hline 2501-3500 TL & 103 & 25,8 \\
\hline $3501-5000 \mathrm{TL}$ & 60 & 15,0 \\
\hline 5001 ve üzeri & 22 & 5,5 \\
\hline Toplam & 400 & 100,0 \\
\hline
\end{tabular}




\section{2. Ölçeğin Güvenilirlik Analizi}

Ölçmede kullanılan anket, ölçek ve testlerin güvenilirlik ve özelliklerini değerlendirmek için geliştirilen güvenilirlik analizinde alfa $(\alpha)$ katsayısına bağlı olarak ölçeğin güvenilirliği aşağıda belirtilen şekilde yorumlanır.

- $\quad 0,00 \leq \alpha<0,40$ ise ölçek güvenilir değildir.

- $\quad 0,40 \leq \alpha<0,60$ ise ölçeğin güvenilirliği düşüktür.

- $\quad 0,60 \leq \alpha<0,80$ ise ölçek oldukça güvenilirdir.

- $\quad 0,80 \leq \alpha<1,00$ ise ölçek yüksek derecede güvenilir bir ölçektir.

Tablo 2: Güvenilirlik Analizi

\begin{tabular}{|l|c|c|}
\hline \multicolumn{1}{|c|}{ Ölçek } & $\begin{array}{c}\text { Cronbach's } \\
\text { Alpha }\end{array}$ & $\begin{array}{c}\text { Madde } \\
\text { Sayısı }\end{array}$ \\
\hline $\begin{array}{l}\text { Bireysel müşterilerin kredi kullanımlarında katılım bankalarını } \\
\text { tercih etme sebepleri }\end{array}$ & 0,915 & 29 \\
\hline
\end{tabular}

Alpha katsayısına göre ölçeğin güvenilirliği yüksek derecede güvenilir düzeydedir $(\alpha=0,915>0,80)$. Örnek hacmi analize oldukça uygundur. Diğer bir ifadeyle örnek rastgele dağılmıştır. Ölçekten soru çıkarmasına veya eklemesine gerek görülmemektedir.

Tablo 3'te ise 29 maddeden oluşan ölçeğe ait madde analiz sonuçları yer almaktadır.

Tablo 3: Ölçeğin Madde Analiz Tablosu

\begin{tabular}{|c|c|c|c|c|}
\hline & \begin{tabular}{|c} 
Madde \\
Çıkarıldığında \\
Ölçek \\
Ortalaması \\
\end{tabular} & \begin{tabular}{|c|} 
Madde \\
Çıkarıldığında \\
Ölçek \\
Varyansı \\
\end{tabular} & $\begin{array}{c}\text { Korelasyon } \\
\text { Katsayıs1 }\end{array}$ & \begin{tabular}{|c|} 
Madde \\
Çıkarıldığında \\
Güvenilirlik \\
Katsayısı \\
\end{tabular} \\
\hline $\begin{array}{l}\text { Çalışmakta olduğum bankam her türlü bankacılık } \\
\text { hizmetini sunmaktadır. }\end{array}$ & 65,98 & 225,007 & ,696 & ,909 \\
\hline Personel ve Hizmet kalitesi yönünden iyidir. & 65,99 & 222,965 & ,686 & ,909 \\
\hline $\begin{array}{l}\text { Tavsiye üzerine ya da kurumda tanıdık birinin } \\
\text { çalışıyor olması müşterilerin tercih etmesinde } \\
\text { etkilidir. }\end{array}$ & 66,06 & 227,237 &, 543 & ,912 \\
\hline $\begin{array}{l}\text { Zamanında ve eksiksiz olarak müşteri taleplerini } \\
\text { karşılayacak kalitede personel bulunmaktadır. }\end{array}$ & 65,74 & 224,857 & ,659 & ,910 \\
\hline $\begin{array}{l}\text { Finansman ve fon fiyatlaması sektördeki yüksek } \\
\text { düzeydeki rekabete ayak uyduracak düzeydedir. }\end{array}$ & 65,32 & 229,425 &, 570 & ,911 \\
\hline $\begin{array}{l}\text { Müşteri işlemleri çok hızlı ve eksiksiz olarak } \\
\text { yapılabilmektedir. }\end{array}$ & 65,43 & 223,243 & ,618 & ,910 \\
\hline
\end{tabular}


The Reasons for Retail Customers' Preference for Participation Banks in their Use of Loans

\begin{tabular}{|c|c|c|c|c|}
\hline $\begin{array}{l}\text { Kriz zamanlarında finansman fiyatlaması sektördeki } \\
\text { ortalamanın üzerinde değişim göstermemiștir. }\end{array}$ & 64,99 & 231,408 & ,409 & ,914 \\
\hline Şube ağı geniştir. & 65,74 & 226,892 &, 508 & ,912 \\
\hline $\begin{array}{l}\text { Bankanın iş yerine olan yakınlığı müşterilerin tercih } \\
\text { etmesinde etkili bir nedendir. }\end{array}$ & 65,73 & 230,855 &, 382 & ,914 \\
\hline Teknolojik gelişmeleri yakından takip eder. & 65,96 & 228,778 &, 561 & ,911 \\
\hline $\begin{array}{l}\text { Bankanın vizyonu ve misyonu beklentilerimi } \\
\text { karşllamaktadır. }\end{array}$ & 65,89 & 220,338 &, 749 & ,908 \\
\hline $\begin{array}{l}\text { Çalıştığım bankamın internet şubesi her türlü } \\
\text { ihtiyacımı karşılamaktadır. }\end{array}$ & 65,83 & 224,155 & ,668 & ,910 \\
\hline Bankanın sunduğu ürün çeşitliliği yeterli düzeydedir. & 65,52 & 227,894 &, 597 & ,911 \\
\hline $\begin{array}{l}\text { TV reklamlarının etkisi müşterileri olumlu yönde } \\
\text { etkilemektedir. }\end{array}$ & 65,91 & 231,094 &, 404 & ,914 \\
\hline $\begin{array}{l}\text { Faizsiz bankacılık uygulaması müşterilerin tercih } \\
\text { etmesinde olumlu etkiye sahiptir. }\end{array}$ & 66,33 & 231,364 & ,475 & ,913 \\
\hline Finansman tahsisinde iş akışı hızlıdır. & 65,37 & 231,682 & ,486 & ,913 \\
\hline $\begin{array}{l}\text { Finansman tahsis politikaları ekonomide yaşanan } \\
\text { olumsuz değişimlerde çok az etkilenmektedir. }\end{array}$ & 64,97 & 236,397 &, 334 & ,915 \\
\hline $\begin{array}{l}\text { Finansman sağlamada istenen evrak ve belgeler fazla } \\
\text { değildir. }\end{array}$ & 64,58 & 234,309 &, 341 & ,915 \\
\hline $\begin{array}{l}\text { Limit tahsis etmede sadece gelir dikkate alınmamakta } \\
\text { aynı zamanda faydaları ve tehditleri de ele } \\
\text { alınmaktadır. }\end{array}$ & 65,20 & 235,756 &, 341 & ,915 \\
\hline $\begin{array}{l}\text { Hesap işletim ücreti, kredi kartı aidatı, havale, eft vs. } \\
\text { gibi işlem masrafları alınmıyor ya da düşük ücretler } \\
\text { alınmaktadır. }\end{array}$ & 64,70 & 232,651 & ,296 & ,915 \\
\hline $\begin{array}{l}\text { Geciken - unutulan borçlar için hemen hatırlatma } \\
\text { yapılmaktadır. }\end{array}$ & 65,61 & 228,554 & ,461 & ,913 \\
\hline $\begin{array}{l}\text { Çağrı merkezine ulaşım kolay, çağrı merkezi hizmeti } \\
\text { hızlı ve sonuç odaklıdır. }\end{array}$ & 65,15 & 228,910 & ,428 & ,914 \\
\hline Finansman oranlarında değişikliğe gitmemektedir. & 64,97 & 236,127 &, 342 & ,914 \\
\hline $\begin{array}{l}\text { Bankamın ürünlerinin İslami açıdan uygunluğunu } \\
\text { onaylayan/denetleyen danışma (fetva) kurulu vardır. }\end{array}$ & 65,88 & 232,711 &, 330 & ,915 \\
\hline ATM ağı geniştir. & 65,78 & 229,735 &, 386 & ,915 \\
\hline ATM kartını alışverişlerde kullanabilirim. & 66,21 & 231,209 &, 555 & ,912 \\
\hline $\begin{array}{l}\text { ATM'lerden fatura ödeme, para yatırma, para çekme } \\
\text { gibi işlemler rahatlıkla yapılabilir. }\end{array}$ & 66,12 & 229,610 &, 592 & ,911 \\
\hline $\begin{array}{l}\text { Banka kartımı sorunsuz olarak her yerde } \\
\text { kullanabilmekteyim. }\end{array}$ & 65,93 & 225,558 & ,606 & ,911 \\
\hline $\begin{array}{l}\text { Banka kartları alışveriş bakımından kullanıma } \\
\text { uygundur. }\end{array}$ & 66,17 & 228,243 & ,605 & ,911 \\
\hline
\end{tabular}

Bartın University Journal of Faculty of Economics and Administrative Sciences, 2021, Issue 12, No 24 
Tablo 3'te madde analiz tablosunda madde çıkarıldığında güvenilirlik katsayısının maddelerinin tümünün karşısındaki değerin 0,915 'ten büyük olmadığ 1 görülmektedir. 29 Yargıdan oluşan ölçeğin güvenilirlik katsayısı 0,915 değeri madde çıkarıldığı zaman artmayacağından ölçekten herhangi bir maddenin çıkarılmasına gerek yoktur.

\subsection{Faktör Analizi}

Faktör analizi, diğer bir ifadeyle aralarında ilişki bulunan çok sayıdaki değişkenden oluşan veri setine ait temel faktörlerin (ilişki yapısının) ortaya konulup veri setinde bulunan kavramlar arasındaki ilişkilerin araştırmacı tarafından kolaylıkla anlaşılmalarına yardımcı olmaktır. Örneklem yeterlilik testi Tablo 4'de gösterilmiştir.

Tablo 4: KMO and Bartlett's Test

\begin{tabular}{|l|l|c|}
\hline \multicolumn{2}{|l|}{ Kaiser-Meyer-Olkin Örnekleme Yeterliliğinin Ölçümü } & 0,917 \\
\hline \multirow{3}{*}{ Bartlett'in Küresellik Testi } & Ki-Kare & 4692,358 \\
\cline { 2 - 3 } & Serbestlik Derecesi & 325 \\
\cline { 2 - 3 } & Anlamlılık & 0,000 \\
\hline
\end{tabular}

Örneklem yeterlilik testi sonucunda KMO (Kaiser-Meyer-Olkin) değeri 0,917 olarak tespit edilmiştir. Bulunan bu değer bize örneklem büyüklüğünün yeterli olduğunu ve faktör analizinin verilerde mükemmel bir şekilde kullanılabileceğini gösterir. Veriler çok değişkenli normal dağılımdan gelen Bartlett testiyle test edilmektedir. Anlamlılık değeri olarak ifade edilen p'nin 0,05 'ten küçük olması analizin anlamlı olduğunu gösterir. Açıklanan toplam varyans tablosu aşağıda gösterilmektedir.

Tablo 5: Açıklanan Toplam Varyans Tablosu

\begin{tabular}{|c|c|c|c|}
\hline \multirow{2}{*}{ Faktörler } & \multicolumn{3}{|c|}{ Kare Yüklerinin Dönme Toplamları } \\
\cline { 2 - 4 } & Toplam & \% Varyans & Kümülatif \% \\
\hline 1 & 4,701 & 18,079 & 18,079 \\
\hline 2 & 3,302 & 12,698 & 30,777 \\
\hline 3 & 3,258 & 12,532 & 43,309 \\
\hline 4 & 2,516 & 9,675 & 52,984 \\
\hline 5 & 1,652 & 6,354 & 59,338 \\
\hline
\end{tabular}

Tablo 5'e göre 29 sorudan oluşan veri setinde toplam 5 faktörün açıklandığ1 görülmektedir. Beş faktörün tamamının veri setini \% 59,338 oranında açıkladığ 1 görülmektedir.

Ölçekte yer alan ifadelerin hangi faktör grubunda yer aldığı ve ifadelerin faktör yüklerinin ne anlama geldiği aşağıdaki Tablo 6'da sunulmuştur. Her ifadenin karşısında 

Participation Banks in their Use of Loans

5 farklı faktör yükü bulunmuştur ve bulunan bu faktör yüklerinden en yüksek olanı alınmıştır.

\section{Tablo 6: Alt Boyutların Belirlendiği Rotasyon Matriks Tablosu}

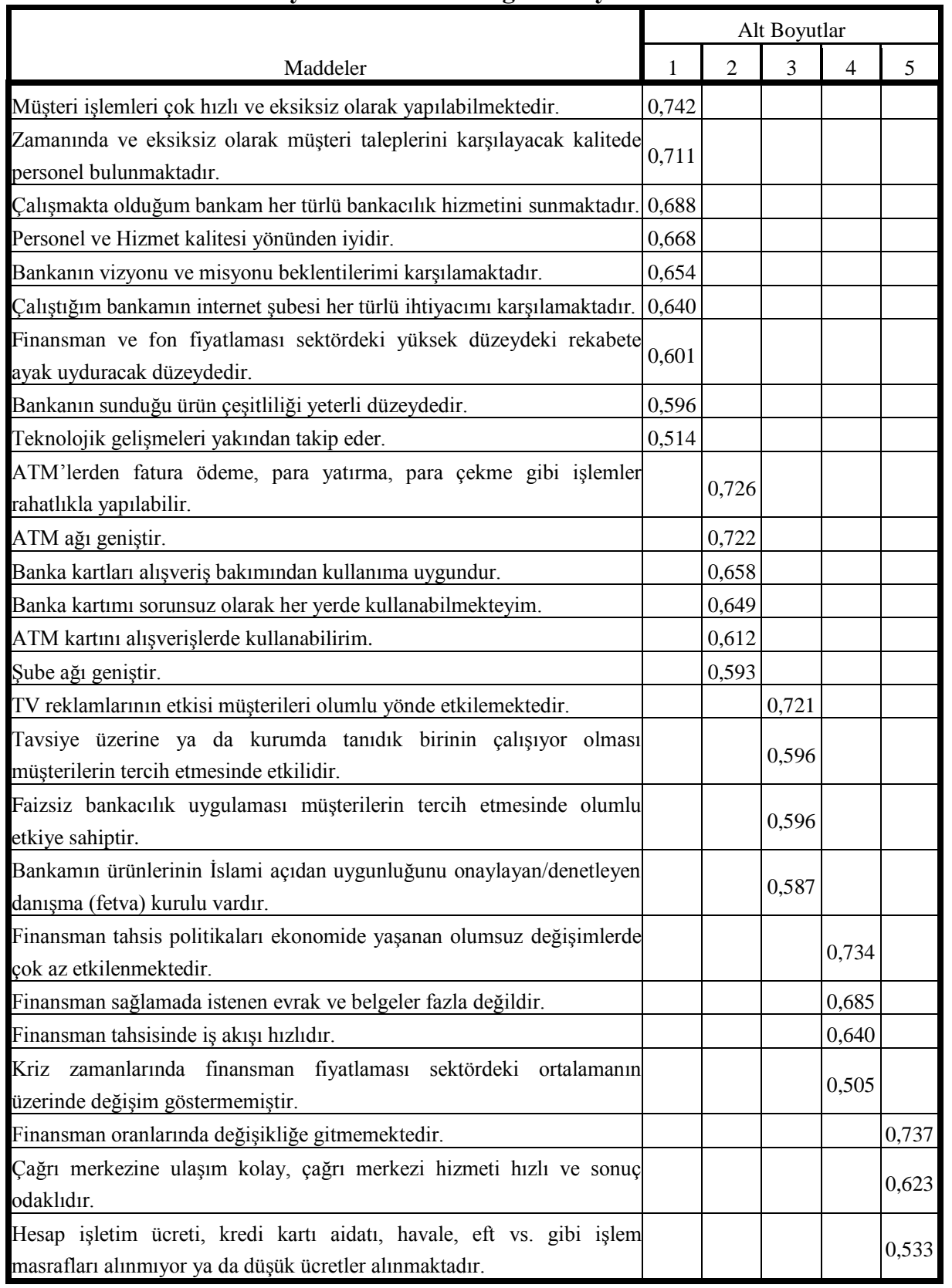

Bartın University Journal of Faculty of Economics and Administrative Sciences, 2021, Issue 12, No 24 
Birinci ifadenin karşısındaki en yüksek değer 0,742; ikinci ifadenin karşısında yer alan en yüksek değer 0,711 ; üçüncü ifadenin karşısında 0,688 ; dördüncü ifadenin karşısında 0,668; beşinci ifadenin karşısında 0,654; altıncı ifadenin karşısında 0,640; yedinci ifadenin karşısında 0,601; sekizinci ifadenin karşısında 0,596; dokuzuncu ifadenin karşısında 0,514 en yüksek değerleri bulunmuştur. $\mathrm{Bu}$ ilk dokuz ifadenin karşısında faktör yüklerinin en yüksek değerleri aynı faktör grubu içerisinde yer almıştır. Diğer ifadelerin en yüksek faktör yükleri karşılarında yer alırken, hangi faktör grubuna girdiği ise en üst satırda gösterilmiştir. İfadelerin dahil olduğu faktörler aşağıdaki Tablo 7'de gösterilmiştir.

Tablo 7: Faktörler ve Faktörlere Ait Güvenilirlik Değerleri

\begin{tabular}{|c|l|l|c|}
\hline $\begin{array}{c}\text { Faktör } \\
\text { No }\end{array}$ & \multicolumn{1}{|c|}{ Faktör İsmi } & \multicolumn{1}{|c|}{ İfadeler } & $\begin{array}{c}\text { Cronbach's } \\
\text { Alpha }\end{array}$ \\
\hline 1 & Hizmet ve Ürün Politikası & $16,17,19,20,21,25,26,27,28$ & 0,903 \\
\hline 2 & Kart Politikası & $23,40,41,42,43,44$ & 0,824 \\
\hline 3 & Faizsizlik Prensibi ve Tanıtımı & $18,29,30,39$ & 0,701 \\
\hline 4 & Tahsis Politikası & $22,31,32,33$ & 0,685 \\
\hline 5 & Alternatif Dağıtım ve Tutundurma Kanalları & $35,37,38$ & 0,621 \\
\hline
\end{tabular}

Hizmet ve Ürün Politikası dokuz yargıdan oluşmaktadır ve bu maddeler kendi aralarında $(\alpha=0,903)$ gibi yüksek bir güvenilirlik derecesine sahiptir. Kart Politikası altı maddeden oluşmakta ve faktörün güvenilirlik katsayısı $(\alpha=0,824)$ olup yüksek derecede güvenilir bulunmuştur. Faizsizlik Prensibi ve Tanıtımı dört maddeden oluşmaktadır. Bu dört maddenin güvenilirlik katsayısı $(\alpha=0,701)$ dir. Tahsis Politikası faktörü de dört maddeden oluşmakta ve $(\alpha=0,685)$ 'dir. Alternatif Dağıtım ve Tutundurma Kanalları üç maddeden oluşmaktadır ve güvenilirlik katsayısı $(\alpha=0,621)$ 'dir.

Tüm faktörler de güvenilirlik katsayıları yüksek olduğundan tamamı analiz yapmak için uygun görülmüştür.

Faktör analizi ile toplam varyansın \% 59,338'ini açıklayan anlamlı beş boyut (faktör) elde edilmiştir.

Birinci faktör, Hizmet ve Ürün Politikası'dır. Güvenilirliği (Cronbach's Alpha) 0,903 olan bu faktör, toplam varyansın \%18,079'unu açıklar ve 9 değişkenden oluşur. Faktörü oluşturan değişkenler Bireysel müşterilerin kredi kullanımlarında katılım bankalarını tercih etmelerini etkileyen hizmet ve ürün politikalarıdır. Faktöre en büyük katkıyı "Müşteri işlemleri çok hızlı ve eksiksiz olarak yapılabilmektedir."(faktör yükü 0,742) sağlamaktadır. En az katkıyı faktöre "Teknolojik gelişmeleri yakından takip eder." (faktör yükü 0,514) sağlar.

İkinci faktör, Kart Politikası'dır. Bu faktör 6 değişkenden oluşur. Faktör kendi arasında 0,824 güvenilirliğe sahiptir. Toplam varyansın \%12,698'ini açıklar. Faktöre en 
büyük katkıyı “ATM'lerden fatura ödeme, para yatırma, para çekme gibi işlemler rahatlıkla yapılabilir." (faktör yükü 0,726) değişkeni sağlar. En az katkıyı ise "Şube ağ1 geniştir." (faktör yükü 0,593) değişkeni sağlamaktadır.

Üçüncü faktör, Faizsizlik Prensibi ve Tanıtımı'dır. Faktör 4 faktörden meydana gelir. Kendi içinde 0,701 güvenilirliğe sahiptir. Toplam varyansın \%12,532'sini açıklamaktadır. Faktöre en yüksek katkıyı "TV reklamlarının etkisi müşterileri olumlu yönde etkilemektedir." (faktör yükü 0,721), en az katkıyı "Bankamın ürünlerinin İslami açıdan uygunluğunu onaylayan/denetleyen danışma (fetva) kurulu vardır." (faktör yükü $0,587)$ sağlamaktadır.

Dördüncü faktör, Tahsis Politikası'dır ve 4 değişkenden oluşmaktadır. Kendi içinde 0,685 güvenilirliğe sahiptir ve toplam varyansın \%9,675'ini açıklamaktadır. Faktöre en büyük katkıyı "Finansman tahsis politikaları ekonomide yaşanan olumsuz değişimlerde çok az etkilenmektedir." (faktör yükü 0,734), en az katkı1ı "Kriz zamanlarında finansman fiyatlaması sektördeki ortalamanın üzerinde değişim göstermemiştir.” (faktör yükü 0,505) sağlamaktadır.

Beşinci faktör, Alternatif Dağıtım ve Tutundurma Kanalları'dır. Üç değişkenden meydana gelir. Kendi içinde 0,621 güvenilirliğe sahiptir. Toplam varyansın \%6,354'ünü açıklamaktadır. Faktöre en büyük katkıyı "Finansman oranlarında değişikliğe gitmemektedir." (faktör yükü 0,737), en az katkıyı "Hesap işletim ücreti, kredi kartı aidatı, havale, eft vs. gibi işlem masrafları alınmıyor ya da düşük ücretler alınmaktadır." (faktör yükü 0,533) sağlamaktadır. Faktörlere yönelik değişkenler incelendiğinde, genellikle bireysel müşterilerin kredi kullanımlarında katılım bankalarını tercih etmelerine ilişkin değerlendirmeleri desteklemektedir.

\subsection{Bireysel Müşterilerin Katılım Bankacılığını Tercih Etme İle İlgili Yargılara Verdiği Yanıtlar}

Aşağıda verilen Tablo 8'de, müşterilerin beşli likert ölçekli sorulara verdiği yanıtların sayısal ve yüzdesel olarak tablosu verilmiştir.

Tablo 8: Bireysel Müşterilerin Kredi Kullanımlarında Katılım Bankalarını Tercih Etme Sebepleri İle İlgili Yargılara Verdiği Yanıtların Dağılımı Tablosu

\begin{tabular}{|c|c|c|c|c|c|c|c|c|c|c|c|c|}
\hline \multirow[t]{2}{*}{ YARGILAR } & \multicolumn{2}{|c|}{ 氞 } & \multicolumn{2}{|c|}{ 言 } & \multicolumn{2}{|c|}{ 䒕 } & \multicolumn{2}{|c|}{ 咅 } & \multicolumn{2}{|c|}{ 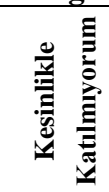 } & \multicolumn{2}{|c|}{$\begin{array}{l}\text { हี } \\
\text { : } \\
\text { : }\end{array}$} \\
\hline & $\mathrm{f}$ & $\%$ & $f$ & $\%$ & $\mathrm{f}$ & $\%$ & $\mathrm{f}$ & $\%$ & $\mathrm{f}$ & $\%$ & $\mathrm{f}$ & $\%$ \\
\hline $\begin{array}{l}\text { Çalışmakta olduğum bankam } \\
\text { her türlü bankacılık hizmetini } \\
\text { sunmaktadır. }\end{array}$ & 123 & 30,8 & 205 & 51,2 & 32 & 8,0 & 35 & 8,8 & 5 & 1,3 & 400 & 100,0 \\
\hline
\end{tabular}


Bireysel Müşterilerin Kredi Kullanımlarında Katılım Bankalarını Tercih Etme Sebepleri Üzerine Bir Araștırma: Bolu Örneği

\begin{tabular}{|c|c|c|c|c|c|c|c|c|c|c|c|c|}
\hline $\begin{array}{l}\text { Personel ve Hizmet kalitesi } \\
\text { yönünden iyidir. }\end{array}$ & 139 & 34,8 & 194 & 48,5 & 18 & 4,5 & 35 & 8,8 & 14 & 3,5 & 400 & 100,0 \\
\hline $\begin{array}{l}\text { Tavsiye üzerine ya da kurumda } \\
\text { tanıdık birinin çalışıyor olması } \\
\text { müşterilerin tercih etmesinde } \\
\text { etkilidir. }\end{array}$ & 167 & 41,8 & 163 & 40,8 & 19 & 4,8 & 44 & 11,0 & 7 & 1,8 & 400 & 100,0 \\
\hline $\begin{array}{l}\text { Zamanında ve eksiksiz olarak } \\
\text { müşteri taleplerini karşllayacak } \\
\text { kaliteder personel } \\
\text { bulunmaktadır. }\end{array}$ & 85 & 21,3 & 201 & 50,2 & 58 & 14,5 & 49 & 12,3 & 7 & 1,8 & 400 & 100,0 \\
\hline $\begin{array}{l}\text { Finansman ve fon fiyatlaması } \\
\text { sektördeki yüksek düzeydeki } \\
\text { rekabete ayak uyduracak } \\
\text { düzeydedir. }\end{array}$ & 46 & 11,5 & 102 & 25,5 & 204 & 51,0 & 43 & 10,8 & 5 & 1,3 & 400 & 100,0 \\
\hline $\begin{array}{l}\text { Müşteri işlemleri çok hızlı ve } \\
\text { eksiksiz } \\
\text { yapılabilmektedir. }\end{array}$ & 57 & 14,2 & 198 & 49,5 & 35 & 8,8 & 94 & 23,5 & 16 & 4,0 & 400 & 100,0 \\
\hline $\begin{array}{lr}\text { Kriz zamanlarında } & \text { finansman } \\
\text { fiyatlaması } & \text { sektördeki } \\
\text { ortalamanın üzerinde değişim } \\
\text { göstermemiştir. }\end{array}$ & 30 & 7,5 & 91 & 22,8 & 166 & 41,5 & 83 & 20,8 & 30 & 7,5 & 400 & 100,0 \\
\hline Şube ağı geniştir. & 112 & 28,0 & 172 & 43,0 & 39 & 9,8 & 66 & 16,5 & 11 & 2,8 & 400 & 100,0 \\
\hline $\begin{array}{l}\text { Bankanın iş yerine olan } \\
\text { yakınlığı müşterilerin tercih } \\
\text { etmesinde etkili bir nedendir. }\end{array}$ & 112 & 28,0 & 173 & 43,3 & 34 & 8,5 & 70 & 17,5 & 11 & 2,8 & 400 & 100,0 \\
\hline $\begin{array}{l}\text { Teknolojik gelişmeleri } \\
\text { yakından takip eder. }\end{array}$ & 128 & 32,0 & 172 & 43,0 & 75 & 18,8 & 19 & 4,8 & 6 & 1,5 & 400 & 100,0 \\
\hline $\begin{array}{l}\text { Bankanın vizyonu ve misyonu } \\
\text { beklentilerimi karşılamaktadır. }\end{array}$ & 131 & 32,8 & 175 & 43,8 & 36 & 9,0 & 47 & 11,8 & 11 & 2,8 & 400 & 100,0 \\
\hline $\begin{array}{l}\text { Çalıştığım bankamın internet } \\
\text { şubesi her türlü ihtiyacımı } \\
\text { karşılamaktadır. }\end{array}$ & 99 & 24,8 & 212 & 53,0 & 33 & 8,3 & 46 & 11,5 & 10 & 2,5 & 400 & 100,0 \\
\hline $\begin{array}{l}\text { Bankanın sunduğu ürün } \\
\text { çeșitliliği yeterli düzeydedir. }\end{array}$ & 52 & 13,0 & 174 & 43,5 & 126 & 31,5 & 40 & 10,0 & 8 & 2,0 & 400 & 100,0 \\
\hline $\begin{array}{l}\text { TV reklamlarının } \\
\text { müşterileri olumisi } \\
\text { etkilemektedir. }\end{array}$ & 139 & 34,8 & 163 & 40,8 & 39 & 9,8 & 53 & 13,3 & 6 & 1,5 & 400 & 100,0 \\
\hline $\begin{array}{l}\text { Faizsiz bankacılık uygulaması } \\
\text { müşterilerin tercih etmesinde } \\
\text { olumlu etkiye sahiptir. }\end{array}$ & 230 & 57,5 & 109 & 27,3 & 42 & 10,5 & 14 & 3,5 & 5 & 1,3 & 400 & 100,0 \\
\hline $\begin{array}{l}\text { Finansman tahsisinde iş akışı } \\
\text { hızlıdır. }\end{array}$ & 41 & 10,3 & 130 & 32,5 & 185 & 46,3 & 37 & 9,3 & 7 & 1,8 & 400 & 100,0 \\
\hline
\end{tabular}


The Reasons for Retail Customers' Preference for

\begin{tabular}{|c|c|c|c|c|c|c|c|c|c|c|c|c|}
\hline $\begin{array}{l}\text { Finansman tahsis politikaları } \\
\text { ekonomide yaşanan olumsuz } \\
\text { değişimlerde çok az } \\
\text { etkilenmektedir. }\end{array}$ & 22 & 5,5 & 48 & 12,0 & 250 & 62,5 & 69 & 17,3 & 11 & 2,8 & 400 & 100,0 \\
\hline $\begin{array}{l}\text { Finansman sağlamada istenen } \\
\text { evrak ve belgeler fazla değildir. }\end{array}$ & 11 & 2,8 & 66 & 16,5 & 115 & 28,7 & 174 & 43,5 & 34 & 8,5 & 400 & 100,0 \\
\hline $\begin{array}{l}\text { Limit tahsis etmede sadece } \\
\text { gelir dikkate alınmamakta ayn } \\
\text { zamanda faydaları ve tehditleri } \\
\text { de ele alınmaktadır. }\end{array}$ & 28 & 7,0 & 105 & 26,3 & 208 & 52,0 & 52 & 13,0 & 7 & 1,8 & 400 & 100,0 \\
\hline $\begin{array}{l}\text { Hesap işletim ücreti, kredi kartı } \\
\text { aidatı, havale, eft vs. gibi işlem } \\
\text { masrafları alınmıyor ya da } \\
\text { düşük ücretler alınmaktadır. }\end{array}$ & 37 & 9,3 & 94 & 23,5 & 48 & 12,0 & 169 & 42,3 & 52 & 13,0 & 400 & 100,0 \\
\hline $\begin{array}{l}\text { Geciken - unutulan borçlar için } \\
\text { hemen hatırlatma } \\
\text { yapılmaktadır. }\end{array}$ & 86 & 21,5 & 188 & 47,0 & 35 & 8,8 & 81 & 20,3 & 10 & 2,5 & 400 & 100,0 \\
\hline $\begin{array}{l}\text { Çağrı merkezine ulaşım kolay, } \\
\text { çağrı merkezi hizmeti hızlı ve } \\
\text { sonuç odaklıdır. }\end{array}$ & 36 & 9,0 & 178 & 44,5 & 32 & 8,0 & 132 & 33,0 & 22 & 5,5 & 400 & 100,0 \\
\hline $\begin{array}{l}\text { Finansman oranlarında } \\
\text { değişikliğe gitmemektedir. }\end{array}$ & 24 & 6,0 & 41 & 10,3 & 264 & 66,0 & 56 & 14,0 & 15 & 3,8 & 400 & 100,0 \\
\hline $\begin{array}{l}\text { Bankamın ürünlerinin İslami } \\
\text { açıdan } \\
\text { onaylayan/denetleyen danışma } \\
\text { (fetva) kurulu vardır. }\end{array}$ & 167 & 41,8 & 81 & 20,3 & 113 & 28,2 & 27 & 6,8 & 12 & 3,0 & 400 & 100,0 \\
\hline ATM ağı geniştir. & 141 & 35,3 & 145 & 36,3 & 28 & 7,0 & 72 & 18,0 & 14 & 3,5 & 400 & 100,0 \\
\hline $\begin{array}{l}\text { ATM kartını alışverişlerde } \\
\text { kullanabilirim. }\end{array}$ & 158 & 39,5 & 204 & 51,0 & 21 & 5,3 & 12 & 3,0 & 5 & 1,3 & 400 & 100,0 \\
\hline $\begin{array}{l}\text { ATM'lerden fatura ödeme, } \\
\text { para yatırma, para çekme gibi } \\
\text { işlemler rahatlıkla yapılabilir. }\end{array}$ & 143 & 35,8 & 204 & 51,0 & 26 & 6,5 & 26 & 6,5 & 1 & 0,3 & 400 & 100,0 \\
\hline $\begin{array}{l}\text { Banka kartımı sorunsuz olarak } \\
\text { her yerde kullanabilmekteyim. }\end{array}$ & 125 & 31,3 & 200 & 50,0 & 17 & 4,3 & 50 & 12,5 & 8 & 2,0 & 400 & 100,0 \\
\hline $\begin{array}{l}\begin{array}{l}\text { Banka kartları alışveriş } \\
\text { bakımından } \\
\text { uygundur. }\end{array} \\
\text { kullanıma }\end{array}$ & 166 & 41,5 & 184 & 46,0 & 23 & 5,8 & 21 & 5,3 & 6 & 1,5 & 400 & 100,0 \\
\hline
\end{tabular}

\subsection{Genel Ortalamadan Farklılığını İnceleyen Tek Örneklem Analizi}

İki grubun ortalaması tek örneklem t testi ile karşılaştırılıp, aradaki fark istatistiksel olarak mı yoksa rastlantısal olarak mı anlamlı olduğuna karar verilmektedir. 
T dağılımı diğer bir ifadeyle küçük örnekleme teorisi, küçük örneklemlerle de çalışmaya uygun olduğundan, araştırmacılar açısından kolaylık sağlar, Bu analiz Tablo 9'da verilmiş̧ir.

Bireysel müşterilerin kredi kullanımlarında katılım bankalarını tercih etme sebeplerinin grup ortalaması olan 2,34'ten istatistiksel olarak anlamlı bir farkl1lık gösterip göstermediğini test etmek için $t$ testi yapılmış ve yapılan uygulama Tablo 9'da gösterilmiştir.

\section{Tablo 9: Katılım Bankacılığını Tercih Etme Nedenlerinin Genel Ortalamadan Farklılığını İnceleyen Tek Örneklem Analizi}

\begin{tabular}{|c|c|c|c|c|c|}
\hline & 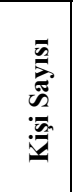 & 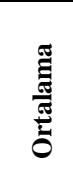 & 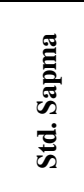 & - & 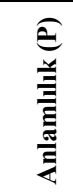 \\
\hline $\begin{array}{l}\text { Çalışmakta olduğum bankam her türlü bankacılık hizmetini } \\
\text { sunmaktadır. }\end{array}$ & 400 & 1,99 & ,923 & 43,013 & 0,000 \\
\hline Personel ve Hizmet kalitesi yönünden iyidir. & 400 & 1,98 & 1,029 & 38,421 & 0,000 \\
\hline $\begin{array}{l}\text { Tavsiye üzerine ya da kurumda tanıdık birinin çalışıyor } \\
\text { olması müşterilerin tercih etmesinde etkilidir. }\end{array}$ & 400 & 1,90 & 1,027 & 37,034 & 0,000 \\
\hline $\begin{array}{l}\text { Zamanında ve eksiksiz olarak müşteri taleplerini } \\
\text { karşılayacak kalitede personel bulunmaktadır. }\end{array}$ & 400 & 2,23 & ,977 & 45,651 & 0,000 \\
\hline $\begin{array}{l}\text { Finansman ve fon fiyatlaması sektördeki yüksek düzeydeki } \\
\text { rekabete ayak uyduracak düzeydedir. }\end{array}$ & 400 & 2,65 & ,866 & 61,137 & 0,000 \\
\hline \begin{tabular}{|l}
$\begin{array}{l}\text { Müşteri işlemleri çok hızlı ve eksiksiz olarak } \\
\text { yapılabilmektedir. }\end{array}$ \\
\end{tabular} & 400 & 2,54 & 1,117 & 45,404 & 0,000 \\
\hline $\begin{array}{l}\text { Kriz zamanlarında finansman fiyatlaması sektördeki } \\
\text { ortalamanın üzerinde değișim göstermemiştir. }\end{array}$ & 400 & 2,98 & 1,018 & 58,522 & 0,000 \\
\hline Şube ağı geniştir. & 400 & 2,23 & 1,111 & 40,130 & 0,000 \\
\hline $\begin{array}{l}\text { Bankanın iş yerine olan yakınlı̆̆ müşterilerin tercih } \\
\text { etmesinde etkili bir nedendir. }\end{array}$ & 400 & 2,24 & 1,122 & 39,878 & 0,000 \\
\hline Teknolojik gelişmeleri yakından takip eder. & 400 & 2,01 &, 914 & 43,951 & 0,000 \\
\hline \begin{tabular}{|llcc}
$\begin{array}{l}\text { Bankanın vizyonu } \\
\text { karşıllamaktadır. }\end{array}$ & ve misyonu beklentilerimi \\
\end{tabular} & 400 & 2,08 & 1,064 & 39,109 & 0,000 \\
\hline $\begin{array}{l}\text { Çalıştığım bankamın internet şubesi her türlü ihtiyacımı } \\
\text { karşılamaktadır. }\end{array}$ & 400 & 2,14 & ,999 & 42,845 & 0,000 \\
\hline Bankanın sunduğu ürün çeşitliliği yeterli düzeydedir. & 400 & 2,45 & ,911 & 53,706 & 0,000 \\
\hline $\begin{array}{l}\text { TV reklamlarının etkisi müşterileri olumlu yönde } \\
\text { etkilemektedir. }\end{array}$ & 400 & 2,06 & 1,053 & 39,120 & 0,000 \\
\hline $\begin{array}{l}\text { Faizsiz bankacılık uygulaması müşterilerin tercih etmesinde } \\
\text { olumlu etkiye sahiptir. }\end{array}$ & 400 & 1,64 & 896 & 36,545 & 0,000 \\
\hline
\end{tabular}



Participation Banks in their Use of Loans

\begin{tabular}{|c|c|c|c|c|c|}
\hline Finansman tahsisinde iş akışı hızlıdır. & 400 & 2,60 &, 859 & 60,500 & 0,000 \\
\hline $\begin{array}{l}\text { Finansman tahsis politikaları ekonomide yaşanan olumsuz } \\
\text { değişimlerde çok az etkilenmektedir. }\end{array}$ & 400 & 3,00 & ,790 & 75,889 & 0,000 \\
\hline $\begin{array}{l}\text { Finansman sağlamada istenen evrak ve belgeler fazla } \\
\text { değildir. }\end{array}$ & 400 & 3,39 & ,951 & 71,203 & 0,000 \\
\hline $\begin{array}{l}\text { Limit tahsis etmede sadece gelir dikkate alınmamakta aynı } \\
\text { zamanda faydaları ve tehditleri de ele alınmaktadır. }\end{array}$ & 400 & 2,76 &, 829 & 66,619 & 0,000 \\
\hline $\begin{array}{l}\text { Hesap işletim ücreti, kredi kartı aidatı, havale, eft vs. gibi } \\
\text { işlem masrafları alınmıyor ya da düşük ücretler } \\
\text { alınmaktadır. }\end{array}$ & 400 & 3,26 & 1,217 & 53,594 & 0,000 \\
\hline $\begin{array}{l}\text { Geciken - unutulan borçlar için hemen hatırlatma } \\
\text { yapılmaktadır. }\end{array}$ & 400 & 2,35 & 1,103 & 42,662 & 0,000 \\
\hline $\begin{array}{l}\text { Çağrı merkezine ulaşım kolay, çağrı merkezi hizmeti hızlı } \\
\text { ve sonuç odaklıdır. }\end{array}$ & 400 & 2,82 & 1,151 & 48,927 & 0,000 \\
\hline Finansman oranlarında değişikliğe gitmemektedir. & 400 & 2,99 & ,796 & 75,164 & 0,000 \\
\hline $\begin{array}{l}\text { Bankamın ürünlerinin İslami açıdan uygunluğunu } \\
\text { onaylayan/denetleyen danışma (fetva) kurulu vardır. }\end{array}$ & 400 & 2,09 & 1,111 & 37,614 & 0,000 \\
\hline ATM ağı geniştir. & 400 & 2,18 & 1,111 & 36,531 & 0,000 \\
\hline ATM kartını alışverişlerde kullanabilirim. & 400 & 1,76 & ,788 & 44,522 & 0,000 \\
\hline $\begin{array}{l}\text { ATM'lerden fatura ödeme, para yatırma, para çekme gibi } \\
\text { işlemler rahatlıkla yapılabilir. }\end{array}$ & 400 & 1,85 & ,826 & 44,660 & 0,000 \\
\hline $\begin{array}{|lcccc|}\begin{array}{l}\text { Banka kartımı } \\
\text { kullanabilmekteyim. }\end{array} & \text { sorunsuz } & \text { olarak } & \text { her } & \text { yerde } \\
\end{array}$ & 400 & 2,04 & 1,018 & 40,085 & 0,000 \\
\hline Banka kartları alışveriş bakımından kullanıma uygundur. & 400 & 1,79 &, 881 & 40,687 & 0,000 \\
\hline \multicolumn{6}{|c|}{ Test Ortalaması $=2.34$} \\
\hline
\end{tabular}

Yüzde 95 güven düzeyine göre yaptığımız t testinde 29 maddenin tamamı, $\alpha=$ 0,05 düzeyinde anlamlı çıkmıştır.

29 yargıdan meydana gelen ölçekte müşteriler her bir yargıya $1=$ Kesinlikle katılıyorum ile $5=$ Kesinlikle katılmıyorum arasında değer vermişlerdir. Grafikte yer alan ortalama değerleri aşağıdaki şekilde yorumlamak mümkündür.

$1,00 \leq$ Ortalama $<1,50$ ise Kesinlikle Kat1liyorum.

$1,50 \leq$ Ortalama $<2,50$ ise Kat1lyorum.

$2,50 \leq$ Ortalama $<3,50$ ise Kararsızım.

$3,50 \leq$ Ortalama $<4,50$ ise Katılmıyorum.

$4,50 \leq$ Ortalama $\leq 5,00$ ise Kesinlikle Katılmıyorum.

Tabloya göre 29 ifadenin 20 tanesinin ortalama eğilimi 1,50 - 2,50 aralı̆̆ında, 9 tanesi de 2,50 - 3,50 aralığında yer almaktadır. 3,5 - 4,5 aralığında yer alan ifade 
bulunmamaktadır. Müşterilerin büyük bir kısmı kredi kullanımlarında katılım bankalarını tercih etme sebepleri ile ilgili ifadelere katılmaktadır.

\subsection{Bireysel Müşterilerin Katılım Bankacılığını Tercihine Etki Eden Faktörlerin Önem Düzeyine Göre Değerlendirilmesi}

Bireylerin, katılım bankalarını tercih etmelerine etki eden sebeplerin önem düzeyine göre değerlendirme sonuçları Tablo 10'da verilmiştir. Katılım bankalarını tercih etme sebeplerinin önem düzeylerine göre değerlendirilmesinde kümele analizinden faydalanılmıştır. Kümeleme analizinin kullanılmasındaki asıl amaç araştırmanın sonunda elde edilen yargıların temel özellikleri göz önüne alınarak katılımcıların gruplandırılmalarını ve önem düzeyini belirlemektir. Analiz sırasındaki yargılarda; 1: Çok önemli, 2: Önemli ve 3: Daha az önemli olacak şekilde gruplandırılmıştır.

\section{Tablo 10: Bireysel Müş̧terilerin Kredi Kullanımlarında Katılım Bankalarını Tercih Etme Sebeplerine Etki Eden Faktörlerin Önem Düzeylerine Göre Değerlendirilmesi}

\begin{tabular}{|c|c|c|c|}
\hline \multirow[b]{2}{*}{ Yargilar } & \multicolumn{3}{|c|}{ Önem Düzeyi } \\
\hline & 1 & 2 & 3 \\
\hline Faizsiz bankacılık uygulaması müşterilerin tercih etmesinde olumlu etkiye sahiptir. & 1,64 & & \\
\hline ATM kartını alışverişlerde kullanabilirim. & 1,76 & & \\
\hline Banka kartları alışveriş bakımından kullanıma uygundur. & 1,79 & & \\
\hline ATM'lerden fatura ödeme, para yatırma, para çekme gibi işlemler rahatlıkla yapılabilir. & 1,84 & & \\
\hline $\begin{array}{l}\text { Tavsiye üzerine ya da kurumda tanıdık birinin çalışıyor olması müşterilerin tercih } \\
\text { etmesinde etkilidir. }\end{array}$ & 1,90 & & \\
\hline Personel ve Hizmet kalitesi yönünden iyidir. & 1,98 & & \\
\hline Çalışmakta olduğum bankam her türlü bankacılık hizmetini sunmaktadır. & 1,99 & & \\
\hline Teknolojik gelişmeleri yakından takip eder. & & 2,01 & \\
\hline Banka kartımı sorunsuz olarak her yerde kullanabilmekteyim. & & 2,04 & \\
\hline TV reklamlarının etkisi müşterileri olumlu yönde etkilemektedir. & & 2,06 & \\
\hline Bankanın vizyonu ve misyonu beklentilerimi karşılamaktadır. & & 2,08 & \\
\hline $\begin{array}{l}\text { Bankamın ürünlerinin İslami açıdan uygunluğunu onaylayan/denetleyen danışma (fetva) } \\
\text { kurulu vardır. }\end{array}$ & & 2,09 & \\
\hline Çalıştığım bankamın internet şubesi her türlü ihtiyacımı karşılamaktadır. & & 2,14 & \\
\hline ATM ağ & & 2,18 & \\
\hline Şube ağı geniştir. & & 2,23 & \\
\hline $\begin{array}{l}\text { Zamanında ve eksiksiz olarak müşteri taleplerini karşılayacak kalitede personel } \\
\text { bulunmaktadır. }\end{array}$ & & 2,23 & \\
\hline Bankanın iş yerine olan yakınlığı müşterilerin tercih etmesinde etkili bir nedendir. & & 2,24 & \\
\hline Geciken - unutulan borçlar için hemen hatırlatma yapılmaktadır. & & 2,35 & \\
\hline
\end{tabular}



Participation Banks in their Use of Loans

\begin{tabular}{|c|c|c|}
\hline Bankanın sunduğu ürün çeşitliliği yeterli düzeydedir. & 2,45 & \\
\hline Müşteri işlemleri çok hızlı ve eksiksiz olarak yapılabilmektedir. & 2,54 & \\
\hline Finansman tahsisinde iş akışı hızlıdır. & 2,60 & \\
\hline $\begin{array}{l}\text { Finansman ve fon fiyatlaması sektördeki yüksek düzeydeki rekabete ayak uyduracak } \\
\text { düzeydedir. }\end{array}$ & 2,65 & \\
\hline $\begin{array}{l}\text { Limit tahsis etmede sadece gelir dikkate alınmamakta aynı zamanda faydaları ve tehditleri } \\
\text { de ele alınmaktadır. }\end{array}$ & 2,76 & \\
\hline Çağrı merkezine ulaşım kolay, çağrı merkezi hizmeti hızlı ve sonuç odaklıdır. & 2,82 & \\
\hline $\begin{array}{l}\text { Kriz zamanlarında finansman fiyatlaması sektördeki ortalamanın üzerinde değişim } \\
\text { göstermemiştir. }\end{array}$ & 2,98 & \\
\hline Finansman oranlarında değişikliğe gitmemektedir. & 2,99 & \\
\hline $\begin{array}{l}\text { Finansman tahsis politikaları ekonomide yaşanan olumsuz değişimlerde çok az } \\
\text { etkilenmektedir. }\end{array}$ & & 3,00 \\
\hline $\begin{array}{l}\text { Hesap işletim ücreti, kredi kartı aidatı, havale, eft vs. gibi işlem masrafları alınmıyor ya da } \\
\text { düşük ücretler alınmaktadır. }\end{array}$ & & 3,26 \\
\hline Finansman sağlamada istenen evrak ve belgeler fazla değildir. & & 3,38 \\
\hline
\end{tabular}

Katılım bankası tercihini etkileyen faktörler arasında ankete katılan müşteriler, "Faizsiz bankacılık uygulaması müşterilerin tercih etmesinde olumlu etkiye sahiptir." yargısına çok yüksek oranda önem vermektedirler. Katılımcılar "Faizsiz bankacılık uygulamasının müşterilerin tercih etmesinde olumlu etkiye sahip olması", "ATM kartının alışverişlerde kullanılabilmesi", "Banka kartlarının alışveriş bakımından kullanıma uygun olması", “ATM'lerden fatura ödeme, para yatırma, para çekme gibi işlemlerin rahatlıkla yapılabilmesi", "Tavsiye üzerine ya da kurumda tanıdık birinin çalışıyor olması müşterilerin tercih etmesinde etkili olması", "Personel ve Hizmet kalitesi yönünden iyi olması" ve "Çalışmakta olduğum bankamın her türlü bankacılık hizmetini sunuyor olması” birinci derecede önemli olarak görülmektedir.

Katılımcılar ikinci dereceden önemli olarak ise "Teknolojik gelişmeleri yakından takip etmesi”, "Banka kartımı sorunsuz olarak her yerde kullanabilmekte olmam", "TV reklamlarının etkisinin müşterileri olumlu yönde etkilemesi" , "Bankanın vizyonu ve misyonu beklentilerimi karşılamakta olması", "Bankamın ürünlerinin İslami açıdan uygunluğunu onaylayan/denetleyen danışma (fetva) kurulunun bulunması", "Çalıştığım bankamın internet şubesinin her türlü ihtiyacımı karşılaması” , “ATM ağ "Şube ağı geniş olması", "Zamanında ve eksiksiz olarak müşteri taleplerini karşılayacak kalitede personel bulunması", "Bankanın iş yerine olan yakınlığının müşterilerin tercih etmesinde etkili olması", "Geciken - unutulan borçlar için hemen hatırlatma yapılması", "Bankanın sunduğu ürün çeşitliliğinin yeterli düzeyde olması", "Müşteri işlemlerinin çok hızlı ve eksiksiz olarak yapılabilmesi", "Finansman tahsisinde iş akışının hızlılığı", “Finansman ve fon fiyatlamasının sektördeki yüksek düzeydeki rekabete ayak uyduracak düzeyde olması", "Limit tahsis etmede sadece gelir dikkate alınmamakta aynı zamanda faydaları ve tehditleri de ele alınmakta olması", "Çağrı merkezine ulaşım 
kolay, çağrı merkezi hizmeti hızlı ve sonuç odaklı olması", "Kriz zamanlarında finansman fiyatlamasının sektördeki ortalamanın üzerinde değişim göstermemiş olması" ve "Finansman oranlarında değişikliğe gitmemesi" katılım bankacılığını tercih etme sebebi olarak ileri sürmüşlerdir.

Katılımcılara göre bireysel müşterilerin kredi kullanımlarında katılım bankalarını tercih etme sebeplerine etki eden faktörler arasında üçüncü dereceden önemli olarak ise "Finansman tahsis politikalarının ekonomide yaşanan olumsuz değişimlerde çok az etkilenmesi" , "Hesap işletim ücreti, kredi kartı aidatı, havale, eft vs. gibi işlem masrafları alınmıyor ya da düşük ücretler alınıyor olması" ve "Finansman sağlamada istenen evrak ve belgelerin fazla olmaması” gibi yargılar sayılmıştır.

\section{Bireysel Müşterilerin Katılım Bankası Tercihinde Demografik Özellikler İle Araştırmanın Boyutları Arasındaki İlişkilerin Hipotez Durumları}

Araştırma bulgularında, bireysel müşterilerin demografik özelliklerinin katılım bankası tercihlerini etkilediği sonucuna varılmıştır. Bireysel müşterilerin katılım bankası tercihinde demografik özelliklerle araştırmanın boyutları arasında ilişkilerin bulunduğu tespit edilmiştir.

Tablo 11: Bireysel Müşterilerin Katılım Bankası Tercihinde Demografik Özellikler İle Araştırmanın Boyutları Arasındaki İlişkilerin Hipotez Durumları

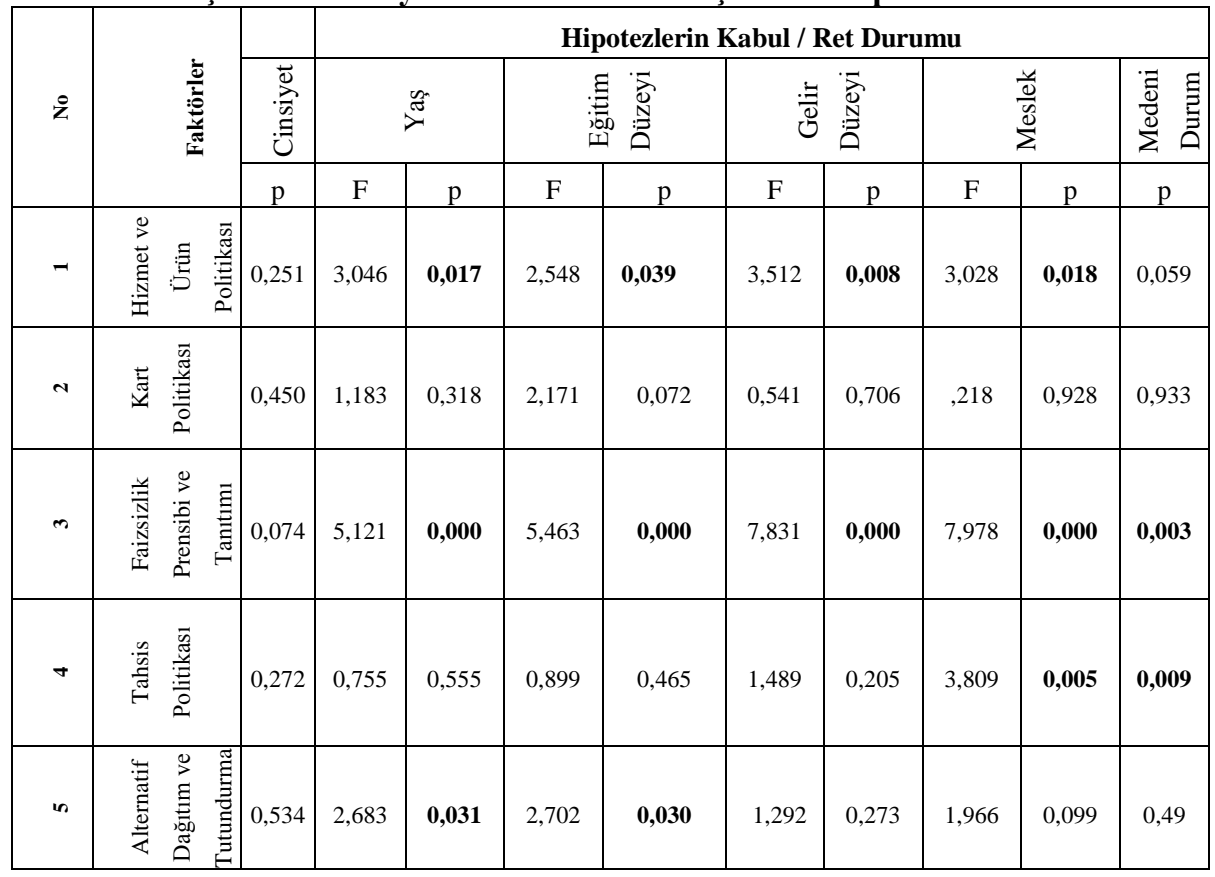



Participation Banks in their Use of Loans

Tablo 11'de görüldüğü üzere "Hizmet ve Ürün Politikası”, "Faizsizlik Prensibi ve Tanıtımı", "Tahsis Politikası" ve “Alternatif Dağıtım ve Tutundurma Kanalları" faktörleri bireysel müşterilerin demografik özellikleri arasında istatistiksel açıdan anlamlı ilişkiler olduğu tespit edilmiştir.

Katılım bankaları sunduğu hizmetleri bireysel müşterilerin demografik özelliklerine göre şekillendirdikçe, bireysel müşterilerin katılım bankalarıyla çalışma yönündeki tercihlerini arttırma eğilimi gösterecektir. Dolayısıyla " $\mathrm{H}_{1}$ : Bireysel müşterilerin demografik özellikleri (bağımsız değişkenler) ile Katılım bankası tercihinde etkili olan faktörler (bağımlı değişkenler) arasında anlamlı bir ilişki vardır”, hipotezi kabul edilmiştir.

\section{Araştırmanın Kısıtlılıkları}

Çalışmada tüm araştırmalarda olduğu gibi metodolojik kısıtlamalar yer almaktadır. Araştırmanın uygulamasında demografik bilgilerden faydalanılmıştır. Katılım bankası ile çalışmayan bireyler araştırmanın dışında tutulmuştur. Araştırmada, araştırma evreninin tamamına ulaşmanın zaman, maliyet ve emek bakımından zor olması sebebiyle, örnekleme metodu benimsenmiştir. Araştırmanın evreni Bolu ilinde bulunan katılım bankası müşterisi 450 bireysel müşteri ile sınırlandırılmıştır.

\section{Sonuç}

Katılım bankacılığı ülkemizde ve dünyada giderek yaygınlaşmakta ve ekonomide önemli bir yere sahip olmaktadır. Tasarruflarını faizsiz bir şekilde değerlendirmek isteyen müşteriler Katılım Bankalarını tercih etmektedir. Faiz hassasiyetine sahip olan ya da olmayan herkes Katılım Bankalarını tercih edebilir. Katılım Bankalarının günümüzde çok sayıda müşterisi vardır.

Yapılan araştırmada, bireysel müşterilerin kredi kullanımlarında katılım bankalarını tercih etmelerini etkileyen sebeplerin neler olduğu ile ilgili sorulara cevap aranmaya çalışılmıştır. Araştırmanın amacı doğrultusunda katılım bankasını tercih eden müşterilerin demografik değişkenleriyle katılım bankası tercihine etki eden faktörler arasında anlamlı bir ilişki olup olmadığı test edilmiştir.

Verilerin analiz edilmesinde SPSS programından yararlanılmıştır. İstatistiksel verileri elde ederken örneklem bilgilerini sayısal bir şekilde özetleyebilmek için betimleyici analiz, ölçeğin güvenilirlik ve geçerliliğini tespit etmek için faktör analizi yapılmıştır. Faktör analizi sonucunda çalışmada yer alan ifadeler beş boyut altında toplanmıştır. Bu boyutlar, Hizmet ve Ürün Politikası, Kart Politikası, Faizsizlik Prensibi ve Tanıtımı, Tahsis Politikası, Alternatif Dağıtım ve Tutundurma Kanalları şeklindedir. Kredi kullanımında katılım bankası tercihini etkileyen faktörlerin demografik 
değiş̧kenlere göre farklılık gösterip göstermediğini tespit etmek için varyans analizi uygulanmıştır. Varyans analizi sonucunun farklı olması durumunda, farklılığın hangi iki değiş̧kenden kaynaklandığını belirleyebilmek için Post Hoc (tukey) testi yapılmıştır. Bireysel müşterilerin kredi kullanımlarında katılım bankasını tercih etmesine yönelik yargıların ortalaması 2,34'tür. İstatistiki açıdan farklı olup olmadığını test etmek için t testi yapılmıştır. Önem düzeyinin belirlenmesinde beşli likert tipi ölçekten faydalanılmıştır. Çalışmadan elde edilen bulgulara göre, bireysel müşterilerin kredi kullanımlarında katılım bankalarını tercih etmesini etkileyen ilk beş özellik;

Faizsiz bankacılık uygulaması müşterilerin tercih etmesinde olumlu etkiye sahiptir.

- $\quad$ ATM karınını alışverişlerde kullanabilirim.

- $\quad$ Banka kartları alışveriş bakımından kullanıma uygundur.

- $\quad$ ATM'lerden fatura ödeme, para yatırma, para çekme gibi işlemler rahatlıkla yapılabilir.

Tavsiye üzerine ya da kurumda tanıdık birinin çalışıyor olması müşterilerin tercih etmesinde etkilidir.

Çalışma sonucunda aşağıdaki öneriler yapılabilir:

- Kart tahsis politikaları geliştirilerek, uygulanan politika yapısı biraz daha esnek hale getirilip kredi hacimleri büyültülebilir.

- Faizsizlik konusuna yaş grubu yüksek olanlar daha çok ilgi göstermektedir. Bu durumda bankalar gençlerin de ilgisini çekeceklerini, güvenini ve beklentilerini karşılayacaklarını kendilerine amaç edinebilirler.

- Kartla ilgili yapılan işlemler bayanların daha çok tercih alanına girmektedir. Cinsiyet ayırt etmeksizin banka kartlarıyla ilgili müşterilere daha çok tanıtım yapılarak avantajlı paketler sunulabilir.

- Faiz konusunda emekli kişiler daha çok hassas oldukları için katılım bankalarını daha çok talep etmektedirler. Emeklilere yönelik kredi işlemlerinde kolaylık yapılırsa müşterinin ilgisi katılım bankalarına daha fazla olacaktır.

- Klasik bankalar ile karşılaştırdığımızda katılım bankalarının şube sayısı ve ATM sayısı daha azdır. Katılımcıların işlemlerini daha kolay halledebilmeleri için yapılacak ATM sayılarındaki artış, müşteri sayısında da artış sağlayabilir. 

Participation Banks in their Use of Loans

- Müşteri ve personel arasında samimi, nezaket, güven ve hoşgörü çerçevesinde bir ilişki oluşturulabilmesi için personele bu konuda eğitim verilebilir.

-Katılım bankalarını uzun yıllar kredi için tercih eden müşterilerin ödüllendirilmesi müşterinin tatmin düzeyini etkiler ve daha uzun yıllar bankanın devamlı müşterisi haline gelebilir.

- Banka müşteriyi, yaş, cinsiyet, eğitim durumlarına göre kampanyalar düzenleyerek bankaya çekmeye çalışmalıdır. Müşterinin memnun olması durumunda banka için devamlı müşteri haline gelebilir.

-Lisans mezunu kişilerde hizmet ve ürün politikalarına yönelik algı daha yüksektir. Bankalardan hizmet alanların eğitim durumları dikkate alınarak yalın bir anlatımla bankanın kredi süreci ile ilgili bilgilendirmeler yapılabilir.

\section{Kaynakça}

ABDUH, Muhamad; Said IBRAHIM and Mohd OMAR; (2012), "A Study on Financegrowth Nexus in Dual Financial System Countries: Evidence from Bahrain", World Applied Sciences Journal, 20 (8), pp. 1166-1174.

Al-Aımı, J., Hussain, H. A. ve Al-Saleh, N. (2009). Clients of conventional and islamic banks in Bahrain: How they choose which bank to patronize. International Journal of Social Economics, 36(11), 1086-1112.

Altıntaş, S. ve Görgen, İ. (2015). Eğitim bilimleri ve öğretmen yetiştirme alanlarında yüksek lisans programlarının incelenmesi: Muğla S1tkı Koçman Üniversitesi Örneği. International Periodical For The Languages, 10(3), 51-78.

Amın, H. (2008). Choice criteria for islamic home financing: Empirical investigation among Malaysian Bank customers. International Journal of Housing Markets and Analysis, 1(3), 256-274.

Anaç, T. ve Kaya, F. (2017). Bireysel müşterilerin katılım bankacılığı tercih etmesini etkileyen faktörler. Bartın Üniversitesi İktisadi ve İdari Bilimler Fakültesi Dergisi,8(15), 145-182.

Bhatti, G. Ali, Hussain, H. ve Akbar, Z. A. (2010). Determinants of customer satisfaction and bank selection in Pakistan. Interdisciplinary Journal of Contemporary Research in Business, 2(6), 536-554.

Durak, İ., Bayat, M. ve Arslan, H.M. (2017). Banka seçiminde müşteri tercihleri: Katılım bankaları üzerine amprik bir inceleme. The Journal of Social Sciences, 1(2), 60-70. 
Dusuki, A.W. ve I.A. Nurdianawati (2007). Why do Malaysian customers patronise islamic banks, International Journal of Bank Marketing, 25(3), 142-160. http://dx.doi.org/10.1108/02652320710739850

Eskici, M. M. (2007). Türkiye’deki katılım bankacılı̆̆ı uygulaması ve katılım bankalarının müşteri özellikleri. Yayınlanmamış yüksek lisans tezi. Süleyman Demirel Üniversitesi, Sosyal Bilimler Enstitüsü, Isparta.

Karakaş İşcan, H. ve Kaya, F. (2019). Bireysel Müşterilerin Kredi Kullanımlarında Katılım Bankalarını Tercih Etme Sebepleri. Yüksek Lisans Tezi, Abant İzzet Baysal Üniversitesi, Sosyal Bilimler Enstitüsü, Bankacılık ve Finans Anabilim Dal1.

Karakaş İşcan, H. ve Kaya, F. (2019, Ekim). Bireysel Müşterilerin Kredi Kullanımlarında Katılım Bankalarını Tercih Etme Sebepleri. 2nd International Conference on Data Science and Applications (ICONDATA'19), Balıkesir, 3-6 Ekim, 275-281.

Karakaya, A ve O. Karamustafa (2004). Bankalarda teknoloji yoğun finansal ürünlerin kullanılmasında müşteri özelliklerinin rolü. Active Bankacılık ve Finans Dergisi, 38: 1-6.

Khattak, N. A. ve Kashif, U. R. (2010). Customer satisfaction and awareness in Islamic banking system in Pakistan. African Journal of Business Management, 4(5), 662671.

Lee, K.H. ve S. Ullah (2011). Customers' attitude toward Islamic banking in Pakistan. International Journal of Islamic and Middle Eastern Finance and Management, $4(2), 131-145$.

Marimuthu, M., Chan, Wai Jing, Lim, Phei Gie, Low, Pey Mun ve Y. P. Tan, (2010). Islamic banking: Selection criteria and implications. Global Journal of Human Social Science, 10(4:1), 52-62.

Okumuş, H. Ş. (2005). Interest-Free Banking in Turkey: A Study of Customer Satisfaction and Bank Selection Criteria. Journal of Economic Cooperation, 26(4), 51-86.

Öndeş, T., Şimşek, A. ve Sumer, S. (2018). Katılım bankalarının kredi kullananlar açısından tercih edilmeme sebepleri: Atatürk üniversitesi akademisyenleri üzerine bir uygulama. Atatürk Üniversitesi İktisadi ve İdari Bilimler Dergisi, 32(4), 897-920. 

Participation Banks in their Use of Loans

Özsoy, İ., Görmez, B., ve S. Melik (2013). Türkiye'de katılım bankalarının tercih edilme sebepleri: Ampirik bir tetkik. Celal Bayar Üniversitesi Yönetim ve Ekonomi Dergisi, 1(10), 187-206.

Ramadan, Z. S. (2013). Jordanian criteria for 1slamic banks selection: Evidence from the jordanian banking sector. International Journal of Academic Research in Accounting, Finance and Management Sciences, 3(3), 139-145.

Şentürk, M., Kaya, F. (2017). Hastanelerin performans uygulamalarında çalışanların memnuniyetini etkileyen faktörler. Bolu Abant İzet Baysal Üniversitesi Sosyal Bilimler Enstitüsü Dergisi, 17(3), 145-174.

Toroman, C., Ata, H.A. ve Buğan, M.F. (2015). İslami bankacılık faaliyetlerine yönelik müşteri algısı üzerine bir araştırma. Gaziantep University Journal of Social Sciences, 14(4), 761-779.

Türkiye Bankalar Birliği (2008). "50.Yılında Türkiye Bankalar Birliği ve Türkiye’de Bankacılık Sistemi 1958-2007”. TBB Bankacılar Dergisi 262:3. 